\title{
The Rules of Balinese Nasalization
}

\section{Made Suwendi}

Faculty of Teacher Training and Education, Indonesian and regional language study programs, Dwijendra University, Bali, Indonesia

\begin{abstract}
Balinese has a stratified system called anggah-ungguhing basa Bali. The existence of this system is distinguished it from Indonesian and / or the other regional languages in Indonesia. In addition, Balinese has two major dialects, namely the Bali Aga dialect and the Bali Dataran dialect. The Bali Aga dialect does not recognize the language level system, on the contrary, in the Bali Dataran dialect this system greatly influences the use of Balinese language itself. The difference in this system was also reflected in its morphological system, especially in forming the words with nasal prefix. It was interesting to be observed. In relation with that, this writing focused on the Balinese nasalization system. The purpose of this research was to find out the rules of Balinese nasalization. The data in this study were collected by using literature study and observation methods. Then, the data were analyzed using descriptive analysis methods. The theory used in investigating this problem was morphology theory. After analyzing the data that had been collected, it was found that the nasal prefix $\{\mathrm{N}-\}$ in Balinese which was affixed to the original form or the basic form which was preceded by certain phonemes, that had already changed form. The form of this changing was called an allomorph. Thus the allomorphs found from the merging of the nasal prefixes were: $n-\{n-\}, m-\{m-\}, n g-\{\eta-\}$., And ny$\{\tilde{n}-\}$.
\end{abstract}

Keywords: The rules, nasalization, Balinese language

*Corresponding Author:

E-mail: suendi1957@gmail.com (I Made Suwendi)

Faculty of Teacher Training and Education, Indonesian and regional language study programs,

Dwijendra University, Bali, Indonesia

\section{INTRODUCTION}

Balinese language is one of the regional languages in Indonesia which is still used as a means of communication and it is maintained by its Balinese speakers. In general, the Balinese has two dalects, namely the Bali Aga dialect and the Bali Dataran dialect. The Bali Aga dialect is often called the Bali Mula dialect or the Bali Pegunungan dialect. Balinese Bali Aga dialect is a Balinese language that has not been influenced by other languages. This Balinese dialect is still used and well maintained by its speaking community, such as in the areas of Sidatapa, Cempaga, Tigawasa, Pedawa, Nusa Penida, and others. Otherwise, the Balinese dialect of Bali

Journal Homepage:

http://ejournal.undwi.ac.id/index.php/jsds
Dataran is Balinese language which has been influence from the other languages. Furthermore, the Balinese language that referred to this paper is the Balinese of Bali Dataran dialect.

The existence of Balinese language is very different from the other regional languages. Balinese language is very unique when it is seen from its system. The uniqueness of the Balinese language is reflected by applying multilevel linguistic system, which is called AnggahUngguhing Basa Bali. The levels of Balinese language referred to Basa Bali Alus (BBA), Basa Bali Madia (BBM), Basa Bali Andap (BBAnd), and Basa Bali Kasar (BBK). In order to speak in Balinese properly and correctly, it is should to know and understand the speech

Copyright (C) 2021 Dwijendra University. All right reserved. 
Journal of Sustainable Development Science

Vol. 3, No. 1, June 2021, pp. 1-8

e-ISSN: 2715-9140 | p-ISSN: 2722-919X

situation and Balinese Anggah-Ungguhing system.

Balinese language has a very important role in the Balinese community life. Balinese is one of the regional languages in Indonesia which is still alive and develop. Balinese language is used as daily communication tool by its speakers, whether they are living or domiciled in Bali or outside Bali. This means that the existence of the Balinese language in its position as a regional language is still well maintained by its speakers, namely the Balinese people. This fact is based on the explanation of the 1945 constitution Chapter XV, Article 36, which stated that regional languages which are properly nurtured by the people must also be preserved by the state. The logical consequence of this explanation is to include it in the school curriculum and do not to equate it with Kawi language or a second foreign language (Halim (ed), 1980: 112).

The growth and development of a language is really depends on the speaker's attitude of that language. In relation with that, the growth and development of the Balinese language today is quite encouraging. It could be seen from the policies taken by the government by issuing regional regulations on Balinese language, literature and script. Balinese language is must be taught in schools from elementary to high school or equivalent. Besides that, the government has also appointed Balinese language instructor who are placed in every village in Bali. This is a very good effort which is done by the government.

On the other hand, there are various problem will occur in the growth and development of Balinese itself. The

Journal Homepage:

http://ejournal.undwi.ac.id/index.php/jsds problems such as the provision of the professional teachers or educators and instructor, the suply of quality and sustainable textbooks, and others. However the complexity of the problems that arise, there is must be a way as long as the government and the Balinese speaking community are always working together in making efforts related to the maintenance and development of the Balinese language itself.

One effort that could be done is to conduct research on the aspects that related to the existence of Balinese, both in its linguistic and non-linguistic aspects. Until now, a lot of research has been done on the Balinese language itself, both by experts and students from various universities in Bali include public or private.

In this regard, it does not mean that the research of Balinese language aspects do not need to be done anymore at this time. Instead, it must be encouraged. This is important to do in order to see the growth and development of the Balinese language, considering that Balinese language has a different system with the other regional languages in Indonesia. Moreover, Balinese language is very dynamic, it means that in its development it always follows its speaker's development.

Viewing on this fact, the writer on this occasion would like to observe on one aspects of the Balinese language, namely its morphological aspects, especially those related to the word formation process, which is called as nasalization process. The observation on this aspect is very important to do, considering the statement above mention that Balinese language has a different system from Indonesian and the other regional languages in Indonesia.

Copyright (C) 2021 Dwijendra University. All right reserved. 
Journal of Sustainable Development Science

Vol. 3, No. 1, June 2021, pp. 1-8

e-ISSN: 2715-9140 | p-ISSN: 2722-919X

In addition, this research will try to pattern or formulate in order to find out the morphological rules of nasal prefixes which is applying in Balinese language. Related to this, the topic raised was "Nasalization Rules in Balinese language".

Purpose

The Understanding of the word formation process, especially in Balinese nasalization process is very important. By understanding this nasalization process, Balinese speakers or users will find it easier to pronounce and understand the meanings of the words that go through the process. In relation to this, the objectives of this research are (1) identifying words with nasal prefixes in Balinese, (2) formulating nasalization rules in Balinese.

\section{METHODS}

Method is a very important component in conducting research or assessment. In relation with that, the method used in examining this problem was literature study method. This method was used to obtain the data required in the analysis. The implementation of this method was assisted by reading and observing techniques some books or literature that were relevant to the problem of Balinese nasalization. Besides that, the observation was done toward the use of Balinese language by its speakers, especially on the teenagers in Denpasar city. Furthermore, the data that has been collected was analyzed by using descriptive qualitative method.

\section{RESULT AND DISCUSSION}

The use of the Balinese language as a means of communication covers various situations, both formal and informal situations. The use of Balinese in formal situations usually refers to the standard variety of Balinese language. On the other hand, in an informal situation, the use of Balinese language refers to or influenced by the dialect (geographic), which is where the speaker comes from. Balinese language Singaraja dialect would certainly different with Denpasar or Badung dialect, Karangasem, and other areas in Bali. The differences between one dialects with another could usually be observed or seen from its vocabulary, the structure of the words or sentences, and the way they are pronounced. Regarding to this study, the data will be obtained from several books and Balinese speakers from Denpasar city. This is done with the consideration that Denpasar city is the center of political, economic, social and cultural activities in Bali. This means that Balinese speakers that was living in Denpasar comes from all regions of Bali. Furthermore, the data that has been collected related to nasalization in Balinese will be analyzed by using morphological theory that refers to the concepts that proposed by Verhaar (1986) in Introduction to Linguistics book, and M. Ramlan (1980) in Morphology book: A Descriptive Review. Furthermore, the data to be observed were Balinese words which are included in verbs category or words that classify as a verb.

\subsection{Nasalization Data in Balinese}

After observing the use of the Balinese language, both in written and spoken data sources, it was found that nasalization events were very dominant in the Balinese language. In relation with that, before analyzing the data, there would be showed some data that were collected in this sub-chapter. For more details data, it could be seen as follows:

Copyright (C) 2021 Dwijendra University. All right reserved. 
Journal of Sustainable Development Science

Vol. 3, No. 1, June 2021, pp. 1-8

e-ISSN: 2715-9140 | p-ISSN: 2722-919X

01. I Kesuna ka glebege nuunang padi. "Si Kesuna climb up to the rice barn and lowered it.".

02. Ia menekan ka pundukane nuduk jaja Beginanne

"He climbs into the paddy fields to take the begina's snack."

03. Raris sambilangipun mikpik don taru majane.

"Then, he plucks the leaves of the maja's tree."

04. Sira makasujatine sane patut mecikang.

"Who is supposed to fix it."

05. Nganti suba tengai ia magae,

"He has been working untill late afternoon."

06. ....... buin lantas tundena ngotol kupingne.

"..... It's told to peck his ear one more

time."

07. Anake ento nyopet dompet tiange ibi di peken.

"That person stole my wallet yesterday at the market."

08. Getepin ja malu, nyanan oke ja nyemuh.

"Cut it first, later I will dry it in the Sun."

09. Salantang jalan kone ia nyelsel awak.

"He regretted himself along the way."

10. Tapinin malu, nyanan oke ja nglesung.

"Sort it first, then, I'll go pound it."

11. Ia jeg pragat ngresikin iba dogen.

"He always cleans himself."

12. Asapunika antuka ngwales piolas anake.

"That's how we appreciate people kindness."

13. I Bapa ngyasang karyane apang antar.

"Father is praying for this event so that

it runs smoothly."

14. ........ngalih yeh sambilanga mandus.

Journal Homepage:

http://ejournal.undwi.ac.id/index.php/jsds
“....... taking some water while

having the shower."

15. Pan Sari ngidih, jaja beginane I

Belog.

"Pan Sari asked for I Belog's begina snack."

16. Lantas ia ngutah-utah.

"Then he vomited."

17. Tiang sedeng ngempok bunga, I

Meme majeritan.

"I was picking the flowers, when

Mom

calls".

18. Ia tusing bani ngorahang kenehne.

"He could not express his feeling."

19. Buka ngentungang uyah ka pasihe.

"Like throwing the salt into the sea".

20. Gede Duarsa ngejuk kedis di abiane.

"Gede Duarsa catches the birds in the garden".

The data above is a small part of the nasalization data that has been collected. This data represents every symptom of nasalization found in Balinese. The following is an analysis of the data that has been collected.

\subsection{The data analysis of Nasalization \\ Process in Balinese \\ Data analysis regarding to the} nasalization process in Balinese will focus on the two important things, namely: 1) the form of nasalization in Balinese, and 2) the patterns or rules changes that occurred in nasalization process.

\subsubsection{The forms of Balinese Nasalization}

The combination of two forms, namely the bound morpheme (prefix) nasal $\{\mathrm{N}-\}$ with the original form or the basic form in Balinese, will cause the form change. The change refers to the change of phoneme (consonant) which initiates the original form or the basic form which undergoes a nasalization process. Besides that, it could be added the sound ng- $[\mathrm{y}-]$ in an original or basic 
Journal of Sustainable Development Science

Vol. 3, No. 1, June 2021, pp. 1-8

e-ISSN: 2715-9140 | p-ISSN: 2722-919X

form. This could be seen on the following analysis.

The words nuunang 'lower' in $1^{\text {st }}$ sentence and nuduk 'take / pick' in $2^{\text {nd }}$ sentence respectively derive from the basic word tuun 'descend' and duduk 'take'. Before going through the nasalization process, the word tuun gets the suffix -ang \{-ang\} first so it becomes tuunang. Placing the nasal prefix $\{\mathrm{N}-\}$ in the tuunang form could change the shape become nuunang. Thus, a change occurs in $/ t /$ consonant which initiates the tuunang form into nuunang, namely $/ t /$ becomes / $n$ /. In contrast to the basic word $d u d u k$, this word immediately changes shape when it gets a nasal prefix, it means that it did not go through another morphological process first. So, the consonant phoneme / $d$ / which starts the word immediately changes become $/ n /$, which come from the form duduk to nuduk.

The words mikpik in the $3^{\text {rd }}$ sentence and mecikang in the $4^{\text {th }}$ went through the same process changing with the words nuunang and nuduk above. The word mikpik comes from the basic word pikpik 'pluck', and mecikang comes from the basic word becik 'good'. The word pikpik was begun with / $p$ /consonant, after being given the nasal prefix $\{N-\}, / p$ $/$ changes into $/ \mathrm{m} /$. While the word becik was begun with / $b$ / consonant, before it was given a nasal prefix $\{\mathrm{N}-\}$, the word was added an affix (affiks) first in the form of the suffix -ang \{-ang\} so that it became becikang. From this form it changes to mecikang after getting the nasal prefix $\{N-\}$. The change that could be seen from this process was the $/ b /$ consonant changes into $/ \mathrm{m} /$. Thus, the words that were begun with / p / or / b / consonant, if it was given the nasal prefix

Journal Homepage:

http://ejournal.undwi.ac.id/index.php/jsds
$\{N-\}$ the / p / or / b /consonant will change into $/ \mathrm{m} /$.

The words $n g a n t i$ in $5^{\text {th }}$ sentence and ngotol in $6^{\text {th }}$ sentence went through the same nasalization process, which was without having the other morphological processes first from the basic word. The word nganti comes from the basic word kanti 'until / to'. This word was started with / $\mathrm{k} /$ consonant, after being given the nasal prefix $\{N-\}$, this consonant changes into $n g-[\eta-]$. It same with the word ngotol, this word came from the word gotol 'patuk'. After being given a nasal prefix, the / g / consonant which was started the word changes into $n g-[\eta-]$. The results of this analysis indicated that the word that was started with / $\mathrm{k} /$ or / g / consonants if it got a nasal prefix, it will change its shape into $n g-[\eta-]$.

The words nyopet in the 7th sentence, nyemuh in the 8th sentence, and nyelsel in the 9th sentence were in the same principle with the word ngotol above, when the basic word was given a nasal prefix, it immediately changes its shape, which means that it did not have to go through another morphological process first. The word nyopet comes from the word copet 'copet', nyemuh comes from the word jemuh 'jemur', and nyelsel comes from the word selsel 'sesal'. Each of those basic words started with the / c /, $/ \mathrm{j} /$, and / s / consonants. After those basic words got or given a nasal prefix, so the/ c /, / j /, and / s / consonants which was starting the basic word change into $n y / \tilde{n}$ /.

It was different with the word nglesung in the $10^{\text {th }}$ sentence, ngresikin in the $11^{\text {th }}$ sentence, ngwales in $12^{\text {th }}$ sentence, and the word ngyasang in $13^{\text {th }}$ sentence. The basic words of each of these words were lesung 'lesung', resik 'clean',

Copyright (C) 2021 Dwijendra University. All right reserved. 
Journal of Sustainable Development Science

Vol. 3, No. 1, June 2021, pp. 1-8

e-ISSN: 2715-9140 | p-ISSN: 2722-919X

wales 'reply', and yasa 'pray'. The basic word lesung begun with the / 1 / consonant, resik is begun with the / $\mathrm{r} /$ consonant, wales started with / w / consonant, and yasa is started with / y / consonant. The basic words that is started with the consonant / / /, / r /, / w /, and / y $/$, if it got the nasal prefix $\{N-\}$, it would not change, but it nasal prefix $\{N-\}$ would show the variation which was in the form of $n g-\{\eta-\}$. In Balinese language (aksara), / 1 /, / $\mathrm{r} / \mathrm{L} / \mathrm{w} /$, and / y / consonants belongs to the arda suara (semi vowel) group.

Likewise with the word ngalih in the $14^{\text {th }}$ sentence, ngidih in $15^{\text {th }}$ sentence, ngutah-utah in $16^{\text {th }}$ sentence, ngempok in $17^{\text {th }}$ sentence, ngorahang in $18^{\text {th }}$ sentence, and ngentungang in $19^{\text {th }}$ sentence. The basic words of each words were alih 'search', idih 'ask', utah 'vomit', empok 'pluck', orah '-', and entung '-', respectively. All these basic words started with a vowel phoneme, such as: / a /, / i /, / u /, / e /, / o /, and / a /. The words such as alih, idih, utah, and empok above could be given the nasal prefix $\{N-\}$ directly, it means that without went through any other morphological process first. Unlike the case with the word or form orah and entung, before being given a nasal prefix, both of the two forms have to went through another morphological process first, such as placing the suffix -ang \{$a \eta\}$, so that it became orahang 'say' and entungang 'throw away'. Thus, if all forms of the words that was begun with a vowel were given a nasal prefix, so it would produce variation form, namely $n g-\{\eta-\}$.

The formation process of the word ngejuk that is contained in the $20^{\text {th }}$ sentence above was different from the other words formation. This word came from the basic word juk 'catch' which was

Journal Homepage:

http://ejournal.undwi.ac.id/index.php/jsds consisting of one syllable. Before it was going through the nasalization process, the sound e [ə] must be added in front of it, so that it became ejuk [əjUk]. Furthermore, from this form, the ngejuk form was born or emerge. Therefore, the nasal prefix that was placed on that form will change into $n g-\{\eta-\}$.

\subsubsection{Nasalization Rules in Balinese}

Viewing on the data analysis above, this section will compile the pattern of nasalization rules in Balinese. The data analysis above showed that:

1) Each original form (basic word) or basic form that was begun with / $\mathrm{t} /$ or / d / consonants, if it got the nasal prefix $\{N-\}$, so the $/ \mathrm{t} /$ or $/ \mathrm{d} /$ consonant will assimilate and it will appear the allomorph $n-\{n-\}$ from it nasal prefix.

Example:

tandur 'tanam' $\rightarrow$ nandur 'menanam'

2) Each original form (basic word) or basic form that was begun with / $\mathrm{p}$ / or / b / consonants, if it got the nasal prefix $\{N-\}$, the consonant of / p / or / $\mathrm{b} /$ will assimilate and it will appear the allomorph $m-\{m-\}$ from it nasal prefix.

Example: paid 'tarik' $\longrightarrow$ maid 'menarik'

3) Each original form (basic word) or basic

form that was begun with / $\mathrm{k} / \mathrm{or} / \mathrm{g} /$ consonants, if it got nasal prefix $\{N-\}$, then the / k / or / g / consonants will assimilate and the allomorph $n g-\{\eta-\}$ of it nasal prefix will appear.

Example: goreng 'goreng' $\longrightarrow$ ngoreng 'menggoreng'

4) Each original form (basic word) or basic All right reserved. 
Journal of Sustainable Development Science

Vol. 3, No. 1, June 2021, pp. 1-8

e-ISSN: 2715-9140 | p-ISSN: 2722-919X

form that begins with the connonant / c

$/, / \mathrm{j} /$, or / $\mathrm{s} /$, if it got the nasal prefix

$\{\mathrm{N}-\}$, then those consonants will

assimilate and the allomorph ng- $\{\mathrm{y}-\}$

of it nasal prefix will appear.

Example:

jait 'jahit' — $\longrightarrow$ nyait 'menjahit'

5) Each original form (basic word) or

basic form that was begun with / $1 /, / \mathrm{r}$

/, / w /, or / y /, if it got the nasal prefix

$\{\mathrm{N}-\}$, then those consonants did not go through assimilation process,

otherwise the allomorph ng- $\{\mathrm{y}-\}$ of it

nasal prefix will appear.

Example:

walek 'ejek' $\longrightarrow$ ngwalek 'mengejek'

6) Each original form (basic word) or basic form that was begun with a vowel phoneme, such as: / a /, / i /, / u $/, / \mathrm{e} /, / \mathrm{o} /$, or $/ \mathrm{a} /$. If it got a nasal prefix $\{\mathrm{N}-\}$, the vowel phoneme did not go through assimilation process, on the contrary, the nasal prefix will show the allomorph ng- $\{\mathrm{n}-\}$.

Example:

arit 'sabit' $\longrightarrow$ ngarit 'menyabit'

7) Each basic word that was consisting of one syllable, if it got the nasal prefix $\{N-\}$, then the word was given by the sound e [ə] in front of it first. After that, the nasal prefix that was affixed in front of it will produce the allomorph $n g-\{\mathrm{n}-\}$.

Example:

yeh 'air' $\rightarrow$ eyehin 'airi' $\longrightarrow$ ngyehin 'mengairi/memberikan air'

TABLE I

Nasalization pattern in Balinese

\begin{tabular}{|c|c|c|c|}
\hline \multirow[t]{2}{*}{$\begin{array}{l}\text { Nasal } \\
\text { Prefix }\end{array}$} & \multirow[t]{2}{*}{$\begin{array}{l}\text { Prefix }\{\mathrm{N}-\} \\
\text { (Allomorph) change }\end{array}$} & \multicolumn{2}{|c|}{$\begin{array}{l}\text { Initial phonemes in basic } \\
\text { word or basic form }\end{array}$} \\
\hline & & $\begin{array}{l}\text { Initial } \\
\text { phoneme } \\
\text { change }\end{array}$ & $\begin{array}{l}\text { Unchanged } \\
\text { initial phoneme }\end{array}$ \\
\hline \multirow{4}{*}{$\mathrm{N}-$} & $n-\{n-\}$ & $/ \mathrm{t} /, / \mathrm{d} /$ & \\
\hline & $m-\{m-\}$ & $/ \mathrm{p} /, / \mathrm{b} /$ & \\
\hline & ny- $\{\tilde{n}-\}$ & $/ \mathrm{c} /, / \mathrm{j} /, / \mathrm{s} /$ & \\
\hline & $n g-\{\eta-\}$ & $/ \mathrm{k} /, / \mathrm{g} /$ & $\begin{array}{l}/ 1, \mathrm{r}, \mathrm{w}, \mathrm{y}, \mathrm{a}, \mathrm{i}, \mathrm{u}, \\
\mathrm{e}, \mathrm{o}, \mathrm{\partial} /\end{array}$ \\
\hline
\end{tabular}

\section{CONCLUSIONS}

Looking at the result of data analysis above, the rules of Balinese nasalization that have been found are:

1) The nasal prefix $\{\mathrm{N}-\}$ in Balinese has $\{n-\}, \quad\{m-\}, \quad\{\tilde{n}-\}, \quad$ and $\quad\{n g-\}$ allomorphs.

2) The allomorph $\{n-\}$ appears, if the nasal prefix is attached to the basic word that starts with the / $\mathrm{t} /$ or $/ \mathrm{d}$ /consonants.

3) The allomorph $\{m-\}$ appears, if the nasal prefix is attached to the basic word that begins with / p / or / b / consonants.

4) The allomorph $\{$ ny- $\}$ appears, if the nasal prefix is attached to the basic word that begins with / $\mathrm{c} /, / \mathrm{j} /$, or / s / consonants.

5) The allomorph $\{y-\}$ appears, if the nasal prefix is attached to the basic word that begins with $/ \mathrm{k} /, / \mathrm{g} /, / 1 /$, / $\mathrm{r} /$, / w /, or / y / consonants, / a /, / i /, / $\mathrm{u} / \mathrm{/} / \mathrm{e} / \mathrm{/} / \mathrm{o} /$, or / a / vowels and a basic word that is consisting of one syllable. 
Journal of Sustainable Development Science

Vol. 3, No. 1, June 2021, pp. 1-8

e-ISSN: 2715-9140 | p-ISSN: 2722-919X

\section{REFERENCES}

Alwasilah, A. Chaedar. 1984. Linguistik Suatu Pengantar. Bandung : Angkasa.

Alwi, Hasan., dkk. 1998. Tata Bahasa Baku Bahasa Indonesia. Jakarta : Balai Pustaka

Bagus, I Gusti Ngurah (ed.). 1975. Masalah Pembakuan Bahasa Bali. Singaraja : Balai Penelitian Bahasa, Dep-dikbud.

Granoka, dkk. Ida Wayan. 1996. Tata Bahasa Baku Bahasa Bali. Denpasar : Pemerintah Daerah Tingkat I Bali.

Kentjono, Djoko. 1982 Dasar-dasar Linguistik Umum. Fakultas Sastra Universitas Indonesia

Kridalaksana, Harimurti. 1982. Kamus Istilah Linguistik. Jakarta : Gramedia.

Parera, Jos Daniel. 2007. Morfologi Bahasa. Jakarta : P.T. Gramedia Pustaka Utama.

Putrayasa, Ida Bagus. 2010. Kajian Morfologi ( Bentuk Derivasional dan Infleksional). Bandung : PT Rafika Aditama.

Ramlah, M. 1978. Ilmu Bahasa Indonesia : Morfologi, Suatu Tinjauan Deskriptif. Yogyakarta : UB Karyono.

Saussure, Ferdinand de. 1988. Pengantar Linguistik Umum (Judul asli; Cours de Linguistique Generale) Terj. Rahayu Hidayat. Yogyakarta: Gajah Mada University Press. 